\title{
Rancang Bangun Sistem Penjualan Furniture Menggunakan Metode Exponential Smoothing
}

\author{
Ambarwati \\ Fakultas Teknologi Informasi, Program Studi Teknik Informatika, Universitas Kristen Satya Wacana, Salatiga, Indonesia \\ Email: ambarvera28@gmail.com \\ Submitted: 24/07/2021; Accepted: 20/08/2021; Published: 31/08/2021
}

\begin{abstract}
Abstrak-Mebel Agung adalah UMKM yang bergerak dalam bidang furniture mebel terletak di daerah kabupaten Semarang. UMKM ini masih melakukan pendataan, pengolahan serta transaksi yang dilakukan secara manual. Proses ini menjadi tidak efektif dan efisien karena dapat terjadi kesalahan dalam pencatatan serta data dapat hilang. Penelitian yang dilakukan ini bertujuan untuk merancang sistem informasi penjualan furniture dan peramalan penjualan menggunakan metode exponential smoothing pada bulan September 2020 sampai Mei 2021. Berdasarkan hasil pengujian analisis penjualan menggunakan metode exponential smoothing dengan menggunakan alpha 0,2 pada bulan mei 2021 perhitungan peramalan permintaan produk furniture sebanyak 41 buah. Hasil perhitungan dengan menggunakan mean square error (MSE) alpha 0.2 untuk memprediksi tingkat kesalahan permintaan mebel adalah: 69,22 = 69. Penelitian sistem ini menggunakan framework codeigniter, dan MySql sebagai database server. Rancang bangun sistem berbasis web dan diharapkan akan mempermudah UMKM untuk melakukan transaksi secara digital serta mengelola data-data barang sehingga laporan data dapat diketahui dengan mudah, cepat, akurat, dan data tersimpan dengan aman.
\end{abstract}

Kata Kunci: Codeigniter; Exponential Smoothing; Penjualan Furniture

\begin{abstract}
Furniture Agung is an MSME engaged in furniture located in the district of Semarang. MSMEs are still conducting data collection, processing and transactions that are carried out manually. This process becomes ineffective and inefficient because errors can occur in recording and data can be lost. This research aims to design an information system for furniture sales and sales forecasting using the exponential smoothing method in September 2020 to May 2021. Based on the results of sales analysis testing using the exponential smoothing method using alpha 0.2 in May 2021, the calculation of forecasting demand for furniture products as many as 41 pieces. The results of calculations using mean square error (MSE) alpha 0.2 to predict the error rate of furniture demand are: $69.22=69$. This system research uses a codeigniter framework, and MySql as a database server. The design of the web-based system is expected to make it easier for MSMEs to conduct digital transactions and manage goods data so that data reports can be known easily, quickly, accurately, and data is stored safely.
\end{abstract}

Keywords: Codeigniter; Exponential Smoothing; Furniture Sales

\section{PENDAhuluan}

Di era modern ini, perkembangan teknologi dari tahun ke tahun mengalami kemajuan yang sangat pesat. Apalagi sekarang orang mudah untuk mendapatkan informasi terkini di belahan dunia dengan cepat dan tepat. Tidak sedikit orang dengan kemajuan teknologi saat ini, mereka mengembangkan teknologi itu agar mempermudah orang lain dalam menggunakannya.Dalam menjalankan sebuah usaha di dunia global yang telah menerapkan teknologi dalam segala aspek menjadi sebuah hal yang harus diperhatikan bagi setiap perusahaan lokal maupun perusahaan nasional [1]. Sistem informasi berbasis web saat ini menjadi suatu hal yang penting dan memberikan kemudahan bagi para penggunanya apalagi di masa pandemi ini banyak orang yang berada di dalam rumah tetapi mereka tetap konsumtif. banyak bidang usaha yang telah memanfaatkan sistem informasi berbasis web sebagai sarana untuk mendapat pelanggan maupun kemudahan dalam berbagai informasi.

Penelitian ini membahas tentang sistem penjualan pada salah satu UMKM (Usaha Menengah Kecil dan Mikro) di kabupaten Semarang, UMKM ini bergerak pada bidang furniture mebel aluminium, produk unggulannya adalah almari pakaian dan lemari perabotan rumah tangga yang terbuat dari alumunium. UMKM ini dalam sistem penjualannya masih menggunakan manual atau pencatatan di buku. Transaksi dalam perusahaan masih berlangsung dengan pelanggan harus datang ke toko, dan karyawan akan menggunakan alat tulis dan buku untuk mencatat pesanan pelanggan. oleh sebab itu mengakibatkan UMKM akan sering mengalami kehilangan data dan dapat terjadi kesalahan yang tidak diinginkan. Hal ini dapat dikatakan kurang efektif dan efisien karena sulit untuk mencatat dan menghitung jika jumlah barang yang diminta banyak, dan jika terjadi kehilangan data maka tidak akan ada laporan penjualan di akhir bulan atau akhir tahun. Untuk mengatasi permasalahan tersebut diperlukan suatu perancangan sistem informasi penjualan berbasis web. Dengan adanya sistem informasi ini diharapkan akan lebih memudahkan pemilik UMKM untuk bertukar informasi tentang rincian produk yang dibutuhkan serta lebih efisien dan efektif dalam pengelolaan transaksi. Hasil penelitian ini akan berbentuk web dengan bahasa pemrograman PHP yang memiliki konsep model-view-controller dengan menggunakan metode Exponential smoothing. Penelitian yang dilakukan Nugroho dkk [2] adalah Pengelolaan data administrasi dan transaksi penjualan pada Mebel Titik Cerah di Banjarsari Solo dilakukan secara manual yaitu dengan pencatatan di buku serta konsumen datang ke toko secara manual. Dari permasalahan tersebut, dapat dilakukan pendekatan untuk memecahkan masalah dengan membuat aplikasi penjualan berbasis android dan menggunakan akses database.

Pada penelitian yang akan dilakukan penulis akan membahas mengenai pembuatan sistem pemesan furnitur meubel akan diterapkan pada Web yang akan menampilkan detail furniture, harga furniture, tampilan fisik 
furniture mebel, serta prediksi penjualan mebel dengan metode Exponential smoothing. Aplikasi yang akan dibangun ini merupakan aplikasi berbasis Web, dimana aplikasi ini akan memanfaatkan web service yang akan menyediakan method database. Dimana method-method tersebut akan memudahkan dalam mengakses database sehingga pengolahan data lebih cepat. CodeIgniter merupakan sebuah open source yang berpondasi dari framework PHP menggunakan model MVC atau juga dianggap contoh View Controller yang pada sistem. dipergunakan untuk membentuk suatu website dinamik menggunakan kode PHP. CodeIgniter membantu para developer untuk bisa menghasilkan suatu aplikasi berbasis website dengan cepat serta tepat dan memberikan kemudahan bagi user [3].

\section{METODOLOGI PENELITIAN}

\subsection{Tahapan Penelitian}

Penelitian ini termasuk golongan Penelitian Kualitatif yang bersifat Deskriptif (cenderung menggunakan analisis). Metode Wawancara dan observasi di lapangan digunakan untuk mengumpulkan data yang dibutuhkan. berikut ini adalah tahapan-tahapan dalam melakukan metode penelitian yang dilakukan:

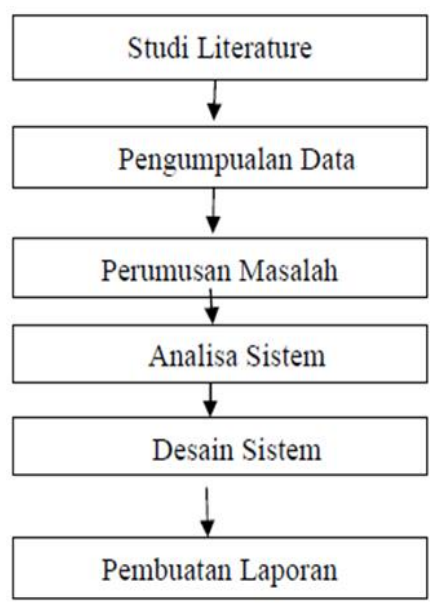

Gambar 1. Tahapan Penelitian

Tahapan penelitian ini dirangkum dalam bentuk gambar kerangka kerja penelitian yang dapat dilihat pada gambar 1 Tahapan penelitian ini dapat diuraikan sebagai berikut [4]:

a. Studi Literatur

Penelitian literatur pada tahap ini dilakukan dengan mempelajari literatur terkait teori exponential smoothing, desain aplikasi berbasis web dan teori codeigniter. Sumber literatur diperoleh dari data yang diperoleh melalui jurnal, artikel, buku referensi, karya ilmiah, dan website pendukung lainnya.

b. Pengumpulan Data

Langkah selanjutnya adalah pengumpulan data. Pengumpulan data dilakukan dengan cara mengamati tokotoko furniture yang ada di wilayah Kabupaten Semarang dan mengumpulkan data-data yang dibutuhkan kemudian melakukan penelitian.

c. Perumusan Masalah

Setelah mengumpulkan data, langkah berikutnya adalah mengembangkan pernyataan masalah terkait dengan masalah yang dihadapi. Bagaimana merancang sistem penjualan furnitur agar lebih mudah digunakan oleh pemilik bisnis dan pelanggan, dan bagaimana menganalisis penggunaan pemulusan eksponensial dalam peramalan penjualan dalam beberapa tahun ke depan.

d. Analisa Sistem dan Desain Sistem

Analisa dilakukan untuk mengetahui rancang bangun yang seperti apa yang mudah digunakan user dalam pemesanan furniture mebel berbasis web. Kemudian setelah itu maka akan dibuat desain sistem pemesanan furniture mebel berbasis web ini.

e. Pembuatan Laporan

Tahap yang terakhir adalah membuat laporan penelitian yang berisi tentang hal yang kita teliti, pembahasan, kesimpulan, serta saran.

\subsection{Metode Exponential Smoothing}

Merupakan pengembangan dari metode moving averages. pada metode ini peramalan dilakukan dengan mengulang data terbaru. Setiap data diberi bobot, data yang lebih baru diberi bobot yang lebih besar. Dua metode dalam exponential smoothing adalah single exponential smoothing dan double exponential smoothing [5], [6].Meramalkan penjualan dengan menentukan perkiraan besarnya volume penjualan, dan menentukan perkiraan 
Journal of Computer System and Informatics (JoSYC)

Volume 2, No. 4, August 2021, Page 280-287

ISSN 2714-8912 (media online)

ISSN 2714-7150 (media cetak)

DOI 10.47065/josyc.v2i4.816

besarnya potensi penjualan dimasa yang akan datang. Berikut ini adalah rumus untuk menghitung exponential smoothing:

$$
\mathrm{St}+1=\alpha \mathrm{Xt}+(1-\alpha) \mathrm{St}
$$

Dimana:

St $+1=$ Nilai ramalan untuk periode berikutnya.

$\alpha=$ Konstanta penulisan (0-1).

$\mathrm{Xt}=$ Data pada periode $\mathrm{t}$.

St = Nilai penulisan yang lama

Nilai konstanta dapat ditentukan menggunakan rumus dibawah ini:

$$
\alpha=2 /(\mathrm{n}+1)
$$

Dimana:

$\mathrm{n}=$ jumlah periode waktu

\section{HASIL DAN PEMBAHASAN}

\subsection{Penerapan Metode Exponential Smoothing}

Permintaan furniture mebel aluminium pada UMKM di kabupaten Semarang mengalami naik dan turun dari bulan ke bulan. Sebelum melakukan forecasting permintaan, terlebih dahulu kita harus menyiapkan data untuk forecasting yaitu data penjualan furniture tahun lalu. Kemudian akan dilakukan forecasting dengan metode exponential smoothing.

Tabel 1. Data penjualan mebel tahun 2020

\begin{tabular}{lc}
\hline Bulan & Permintaan \\
\hline September & 30 \\
Oktober & 40 \\
November & 35 \\
Desember & 50 \\
Januari & 42 \\
Februari & 45 \\
Maret & 50 \\
April & 30 \\
Mei & 55 \\
\hline
\end{tabular}

Dalam hal ini penulis memilih jangka waktu yang akan diramalkan antara bulan September 2020 sampai bulan Mei 2021. Maka dalam metode ini $\alpha$ yang akan dipakai adalah 0,2. Metode Exponential Smoothing $(\alpha=$ $0.2)$.

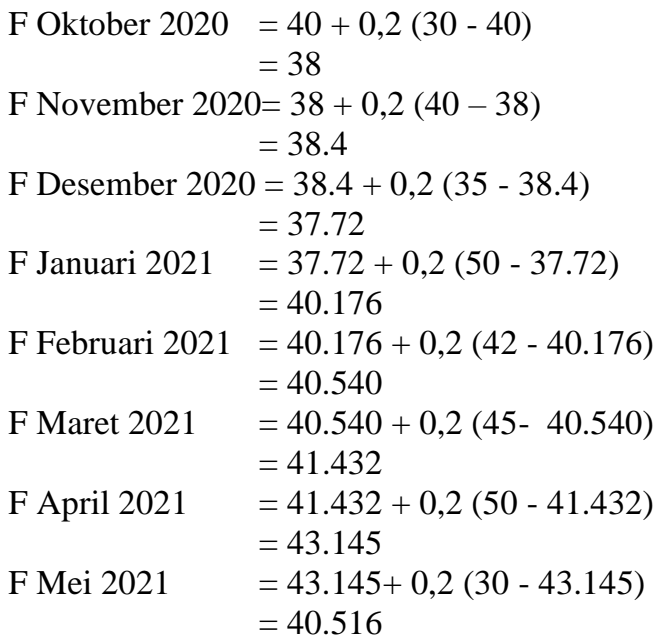

Karena data berupa data permintaan furniture mebel, maka tidak mungkin hasilnya berupa pecahan, maka untuk itu hasil pecahan dibulatkan dengan syarat:

0 - 0,499 Dibulatkan menjadi 0

0,5 - 0,999 Dibulatkan menjadi 1 
Journal of Computer System and Informatics (JoSYC)

Volume 2, No. 4, August 2021, Page 280-287

ISSN 2714-8912 (media online)

ISSN 2714-7150 (media cetak)

DOI 10.47065/josyc.v2i4.816

Tabel 2. Peramalan Permintaan Tahun 2020

\begin{tabular}{lcl}
\hline Bulan & Permintaan & Forecast \\
\hline September & 30 & - \\
Oktober & 40 & 38 \\
November & 35 & 38 \\
Desember & 50 & 38 \\
Januari & 42 & 40 \\
Februari & 45 & 41 \\
Maret & 50 & 41 \\
April & 30 & 43 \\
Mei & 55 & 41 \\
\hline
\end{tabular}

Tabel 2 Menampilkan perbandingan prediksi permintaan furniture menggunakan metode exponential smoothing alpha 0.2. Dapat dilihat dari Tabel 3.6 bahwa penulis tidak dapat memprediksi pada bulan September 2020 karena tidak ada data perkiraan untuk periode sebelumnya. maka penulis menggunakan data terdekat untuk memprediksi bulan Oktober 2020 yaitu September 2020. Perhitungan kesalahan ditunjukkan pada tabel berikut:

Tabel 3. Hasil perhitungan dengan metode exponential smoothing

\begin{tabular}{lccccc}
\hline Bulan & Permintaan & Forecast & Error & $\begin{array}{c}\text { Abs } \\
\text { error }\end{array}$ & Error2 \\
\hline September & 30 & - & - & - & - \\
Oktober & 40 & 38 & 2 & 2 & 4 \\
November & 35 & 38 & -3 & 3 & 9 \\
Desember & 50 & 38 & 12 & 12 & 144 \\
Januari & 42 & 40 & 2 & 2 & 4 \\
Februari & 45 & 41 & 4 & 4 & 16 \\
Maret & 50 & 41 & 9 & 9 & 81 \\
April & 30 & 43 & -13 & 13 & 169 \\
Mei & 55 & 41 & 14 & 14 & 196 \\
\hline Jumlah & & & & 59 & 623 \\
Rata-Rata & & & & 6.5 & 69.22 \\
\hline
\end{tabular}

Pada tabel 3 dengan menggunakan metode exponential smoothing Alpha 0.2 untuk memprediksi deviasi (kesalahan) permintaan produk mebel adalah kesalahan absolut rata-rata 6,5 dan kesalahan kuadrat rata-rata 69,22 $=69$.

\subsection{Rancangan Use Case Diagram}

Perancangan sistem yang dilakukan dalam penelitian ini menggunakan UML (Unified Modeling Language). UML dalam penelitian ini terdiri dari: use case diagram, activity diagram, dan class diagram. Use case diagram merupakan rancangan sistem informasi yang akan dibuat pemodelan untuk kelakuan sistem informasi yang akan dibuat. Use case bekerja dengan mendeskripsikan tipikal hubungan antara user sebuah sistem dengan sistemnya sendiri melalui sebuah cerita bagaimana sistem itu digunakan [7][8]. Pemodelan ini digunakan sebagai penyederhanaan permasalah yang kompleks sehingga dapat mudah dipelajari dan mudah dipahami:

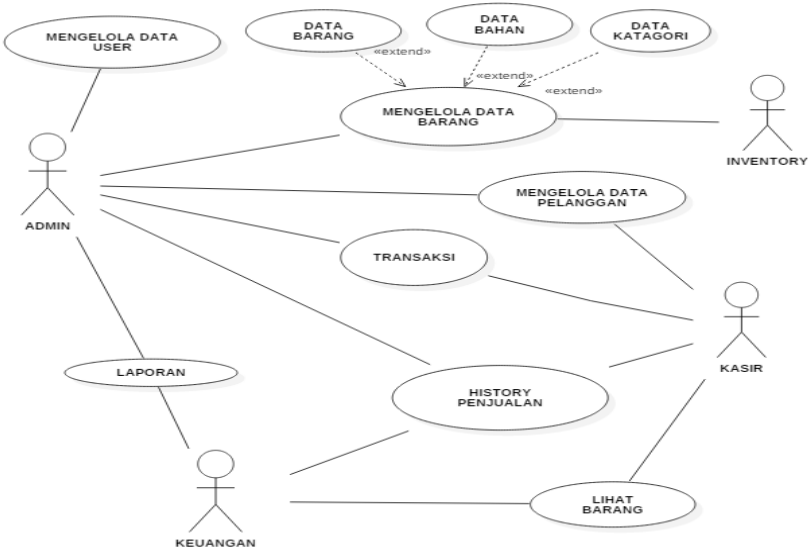

Gambar 2. Use Case Diagram 
Gambar 2 merupakan use case diagram dari aplikasi sistem informasi penjualan furniture berbasis website. Aplikasi tersebut memiliki 4 aktor yaitu admin, inventory, kasir, dan keuangan. admin memiliki hak untuk mengelola semua data website. Untuk inventory hanya dapat mengelola data barang. Sedangkan untuk kasir dapat mengelola data pelanggan, transaksi, history penjualan, dan melihat data barang. Untuk keuangan memiliki hak dapat mengelola history penjualan, laporan penjualan, dan melihat data barang.

\subsection{Perancangan Database}

Database adalah kumpulan data yang distrukturkan sehingga memungkinkan kemudahan dalam melakukan proses untuk menghasilkan suatu informasi sehingga dapat mempermudah dalam mencapai tujuan kerja [9]. Berikut ini adalah perancangan struktur database, tabel dan relasinya yang digunakan dalam pembuatan aplikasi sistem informasi Penjualan Furniture adalah sebagai berikut:

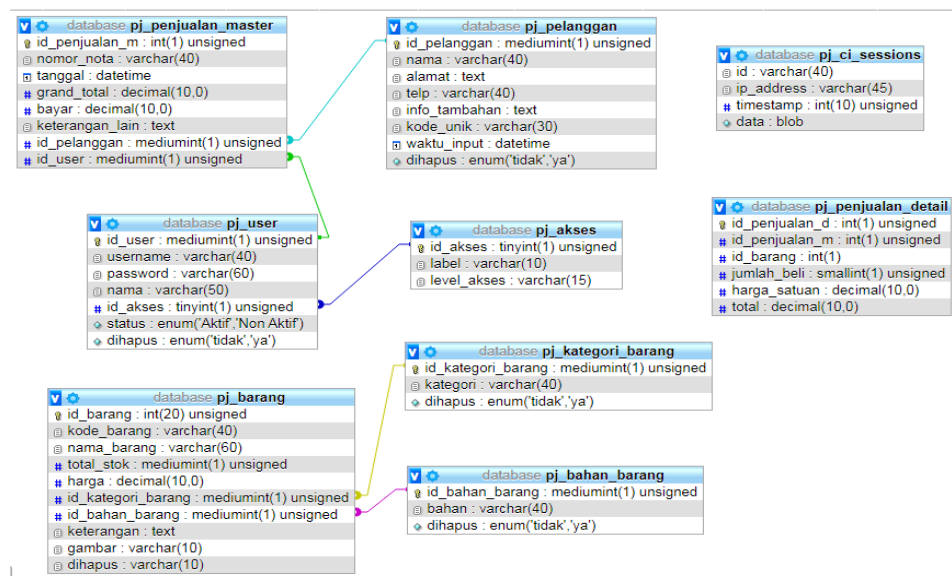

Gambar 3. Database Sistem Informasi Penjualan Furniture

Class Diagram adalah penjelasan atau alur jalannya database pada sebuah sistem. Dalam class diagram biasanya terdiri dari beberapa kelas yang mempunyai relasi satu sama lain. Dijelaskan pada gambar bahwa terdapat beberapa Class yang saling berhubungan. Class pj penjualan menyimpan data berupa detail penjualan, Class pengguna menyimpan data pengguna, Class pelanggan menyimpan data pelanggan, kategori produk menyimpan data kategori produk, kategori barang menyimpan data produk, kategori detail penjualan pj menyimpan data penjualan terinci data, dan kategori barang dan bahan pj menyimpan data bahan.

\subsection{Tampilan User Interface}

User Interface adalah saat sistem dan pengguna dapat saling berinteraksi satu dengan lainnya melalui perintah seperti halnya menggunakan konten dan memasukkan data [10]. Pengguna diharapkan mampu memahami penggunaan komponen website dengan melihat desain tampilan sehingga pengguna dapat menggunakan setiap fitur secara mudah. Berikut merupakan gambaran serta penjelasan sistem dari aplikasi penjualan furniture:

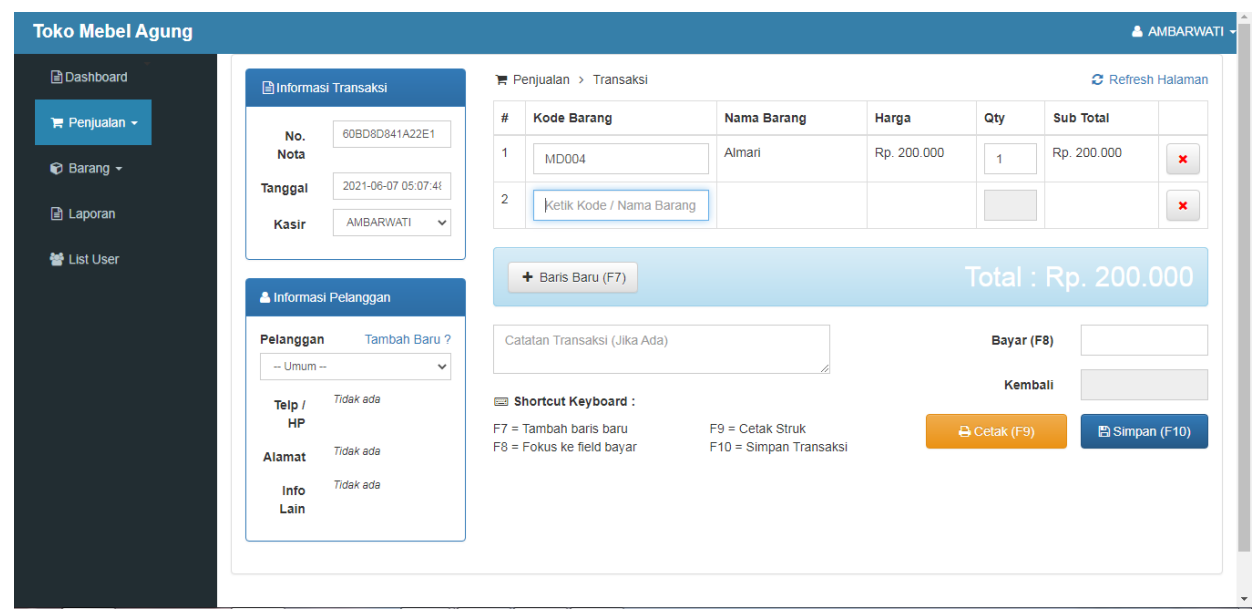

Gambar 4. Tampilan menu transaksi

Gambar 4 adalah tampilan dari sub menu transaksi. Tampilan ini berfungsi untuk mencatat transaksi yang dilakukan oleh kasir atau admin. Kasir atau admin memilih kode barang yang tersedia kemudian akan muncul rincian nama barang, harga. Kemudian memilih kuantitas yang akan dibeli lalu subtotal harga akan otomatis muncul. Kasir atau admin akan menginput nominal uang yang dibayarkan maka kembalian akan otomatis terisi, 
Journal of Computer System and Informatics (JoSYC)

Volume 2, No. 4, August 2021, Page 280-287

ISSN 2714-8912 (media online)

ISSN 2714-7150 (media cetak)

DOI 10.47065/josyc.v2i4.816

kemudian admin atau kasir dapat memilih tombol simpan untuk menyimpan transaksi dan menekan tombol cetak untuk mencetak nota transaksi. Di halaman ini juga terdapat informasi tentang transaksi dan informasi tentang pelanggan.

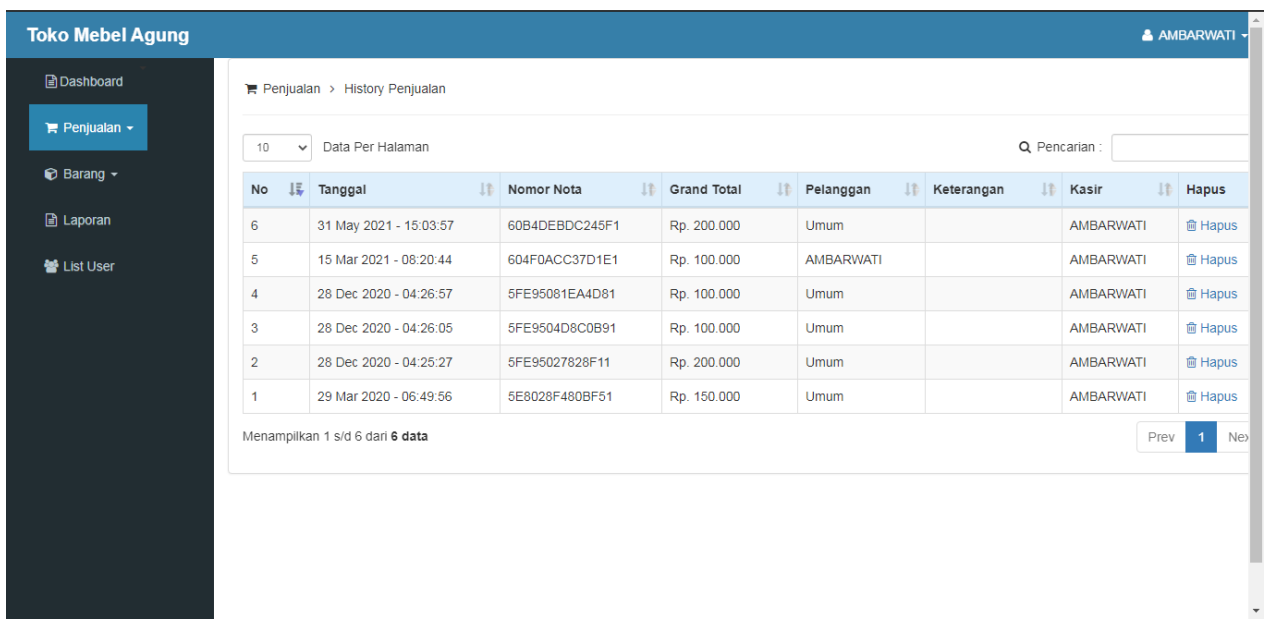

Gambar 5. Tampilan menu history penjualan

Gambar 5 merupakan tampilan menu history penjualan dimana di halaman ini terdapat tanggal pembelian, nomor nota, grand total, jenis pelanggan, keterangan nota, dan nama kasir.

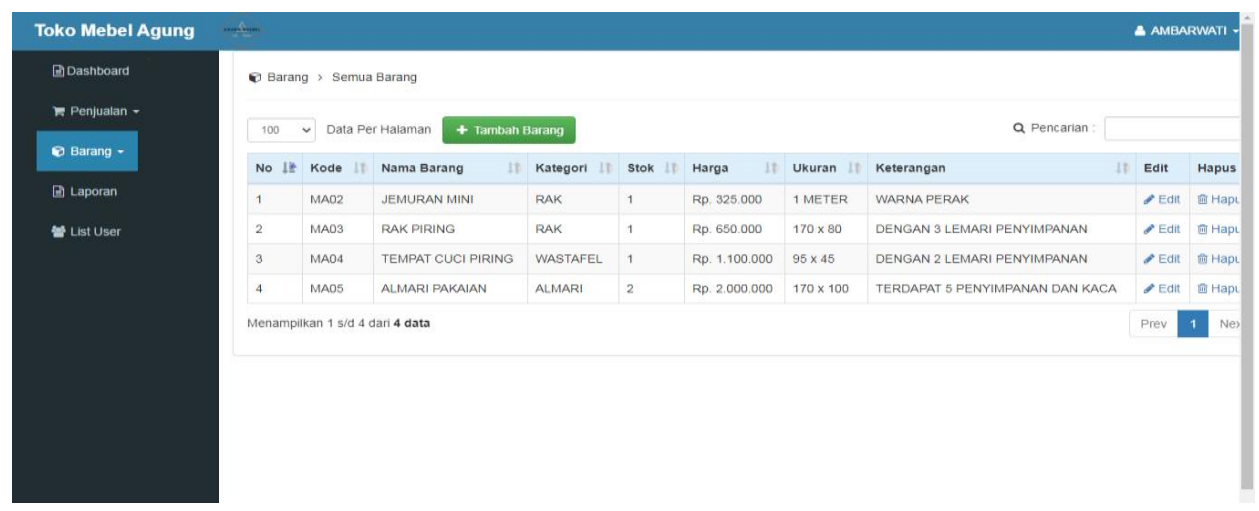

Gambar 6. Tampilan menu barang

Gambar 6 merupakan tampilan menu dari data barang. di halaman ini terdapat kode barang, nama barang, kategori barang, stok barang, harga barang, ukuran barang, dan keterangan. Terdapat juga button tambah barang, edit dan hapus tetapi hanya bisa dilakukan oleh admin dan inventory.

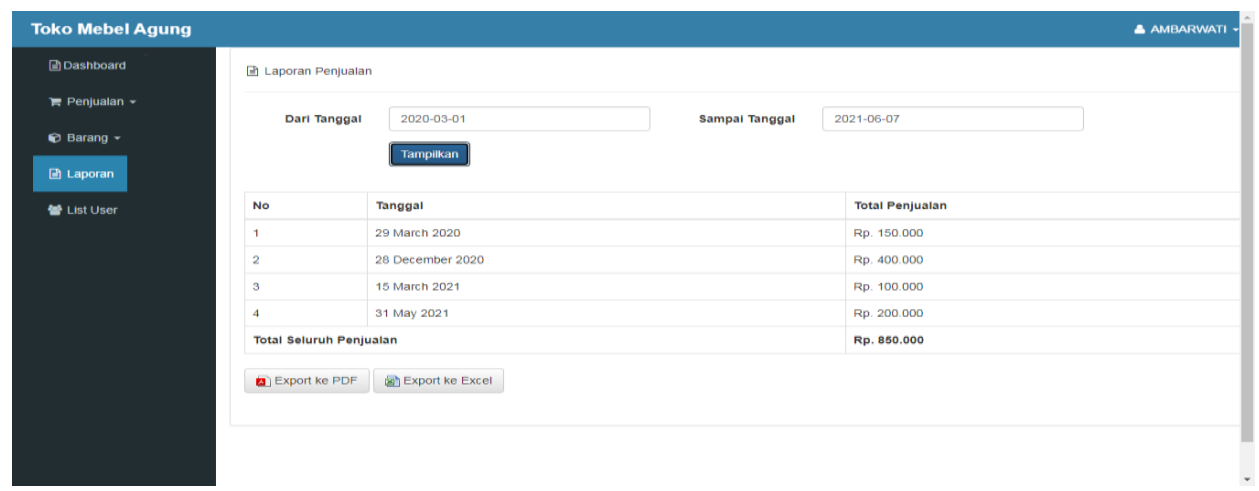

Gambar 7. Tampilan menu laporan

Gambar 7 merupakan tampilan menu laporan. Di halaman ini admin atau inventory dapat memilih laporan penjualan berdasarkan tanggal yang diinginkan. kemudian admin atau inventory dapat mengexport laporan kedalam bentuk PDF atau Excel. 


\begin{tabular}{|c|c|c|c|c|}
\hline $\begin{array}{l}\text { Nota : } \\
\text { Tanggal : } \\
\text { Kasir } \\
\text { Pelanggan : }\end{array}$ & $\begin{array}{l}\quad \text { Selamat Datang } \\
\text { 60C18DC4763FD1 } \\
\text { 10-Jun-2021 05:57:56 } \\
\text { AMBARWATI } \\
\text { umum }\end{array}$ & Toko Mebe & Agung & \\
\hline Kode & Item & Harga & Oty & Subtotal \\
\hline \multirow[t]{2}{*}{ MAO1 } & JEMURAN MINI & 2.000 .000 & 1 & 2.000 .000 \\
\hline & & & $\begin{array}{r}\text { Total Bayar } \\
\text { Cash } \\
\text { Kembali }\end{array}$ & $\begin{array}{l}2.000 .000 \\
2.000 .000 \\
0\end{array}$ \\
\hline $\begin{array}{l}\text { Catatan : } \\
\text { Tidak Ada }\end{array}$ & & & & \\
\hline
\end{tabular}

Gambar 8. Tampilan Nota Pembelian

Gambar 8 merupakan tampilan nota jika sudah dicetak. Di halaman ini terdapat no nota, tanggal pembelian, nama kasir, nama pelanggan, detail barang yang dibeli beserta harga dan berapa uang yang dibayarkan.

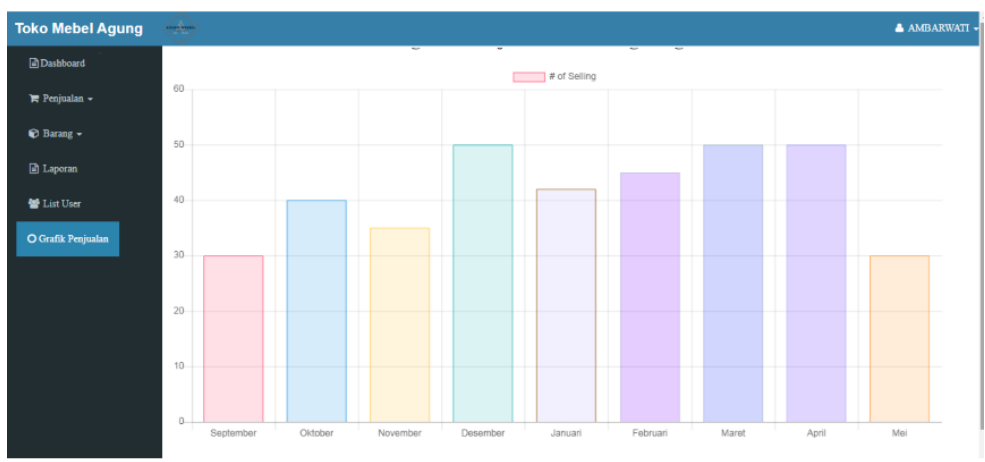

Gambar 9. Tampilan Grafik Penjualan

Gambar 9 merupakan tampilan data penjualan mebel agung pada bulan September 2020 sampai Mei 2021 yang disajikan dalam bentuk diagram batang.

\section{KESIMPULAN}

Berdasarkan penelitian dan perancangan terhadap sistem, maka dapat disimpulkan bahwa sistem ini dapat membantu perusahan dalam proses akuntansi, perusahaan memungkinkan data dapat disimpan dengan baik dan rapi. Selain itu website ini juga dapat membantu perusahaan dalam memproses transaksi pembelian dalam bentuk digital sehingga mengurangi hilangnya bukti transaksi. Berdasarkan hasil pengujian analisis penjualan menggunakan metode exponential smoothing maka dapat disimpulkan bahwa dengan menggunakan alpha 0,2 pada bulan mei 2021 perhitungan peramalan permintaan produk furniture sebanyak 41 buah. Hasil perhitungan dengan menggunakan mean square error (MSE) alpha 0.2 untuk memprediksi tingkat kesalahan permintaan mebel adalah: $69,22=69$.

\section{REFERENCES}

[1] T. G. Yuarita, F. Marisa, J. T. Informatika, and U. W. Malang, "PERANCANGAN APLIKASI POINT OF SALES ( POS ) BERBASIS WEB MENGGUNAKAN METODE SIKLUS HIDUP,” pp. 167-171, 2017.

[2] E. C. Nugroho and A. N. Pratiwi, "Aplikasi Penjualan Mebel Titik Cerah Berbasis Android,” vol. 24, no. 2, pp. 95-109, 2018, doi: 10.36309/goi.v24i2.89.

[3] F. Rahman, "PERANCANGAN E-LEARNING BERBASIS WEB MENGGUNAKAN FRAMEWORK CODEIGNITER," vol. 9, no. 2, pp. 95-100, 2018.

[4] A. R. Dewi, "Analisis Sistem Informasi Pengolahan Data Nilai Mahasiswa Menggunakan PIECES pada Prodi Sistem Informasi," Query, vol. 5341, no. October, pp. 37-46, 2018.

[5] Kurniagara, "PENERAPAN METODE EXPONENTIAL SMOOTHING DALAM MEMPREDIKSI JUMLAH SISWA BARU ( STUDI KASUS : SMK PEMDA LUBUK PAKAM ),” vol. 6, pp. 19-25, 2017.

[6] T. Tedy and S. Saputra, "Analisa Akurasi Penggunaan Metode Single Eksponential Smoothing untuk Perkiraan Penerimaan Mahasiswa Baru Pada Perguruan Tinggi XYZ,” vol. 11, no. 01, pp. 64-68, 2020.

[7] D. Wira, T. Putra, and R. Andriani, "Unified Modelling Language ( UML ) dalam Perancangan Sistem Informasi Permohonan Pembayaran Restitusi SPPD,” vol. 7, no. 1, 2019. 
Journal of Computer System and Informatics (JoSYC)

Volume 2, No. 4, August 2021, Page 280-287

ISSN 2714-8912 (media online)

ISSN 2714-7150 (media cetak)

DOI 10.47065/josyc.v2i4.816

[8] Sutejo, "Pemodelan UML Sistem Informasi Geografis Pasar Tradisional Kota Pekanbaru," vol. 1, no. 2, pp. 192-206, 2020.

[9] R. Kurniawan, "Perancangan Sistem Basis Data Pada Aplikasi Sistem Penjawab Soal Pilihan Ganda," 2016.

[10] H. Joo, "A Study on Understanding of UI and UX , and Understanding of Design According to User Interface Change," vol. 12, no. 20, pp. 9931-9935, 2017. 